\title{
Clemizole Hydrochloride
}

National Cancer Institute

\section{Source}

National Cancer Institute. Clemizole Hydrochloride. NCI Thesaurus. Code C81152.

The hydrochloride salt form of clemizole, an orally bioavailable histamine $\mathrm{H} 1$ antagonist, with potential anti-tumor and anti-allergic activities. Upon oral administration, clemizole binds to and blocks the $\mathrm{H} 1$ receptor, thereby preventing the interaction between histamine and the $\mathrm{H} 1$ receptor and inhibiting $\mathrm{H} 1$-mediated signaling. This may inhibit or prevent the symptoms that are caused by histamine activity and rescues or prevents allergic reactions. Although the exact mechanism of action by which clemizole appears to exert its antineoplastic effect is yet to be elucidated, clemizole inhibits the proliferation of certain tumor cell types. 